\title{
University of California Strawberry Breeding
}

Hedrick (1925, p. 355) states in the introduction to the strawberry sections of The Small Fruits of New York

"The Strawberry has remarkable powers of adapting itself to climates and soils. In consequence it is found in one species or another in almost every part of the globe. But in general the many species are lovers of cool climates and of dry, loose, warm soils. Under culture strawberries belong distinctly to cold climates. In tropical' and sub-tropical countries, the plants grow but languidly, refuse to bear abundantly, and the fruits are deficient in size, color, flavor, and the delicate fragrance from which the strawberry derives its generic name Fragaria. The plants are most luxuriant, and the fruits are most pleasing to eye and palate where greatest hardihood to cold is required. Wild or cultivated, strawberries are little esteemed to warm countries. Accordingly, they are valued most, and came to their present high estate as cultivated plants in the colder parts of the temperate zones, especially in Europe and North America, to whose peoples they owe domestication."

Most of the above statements were true at that time because the breeding of strawberries for adaptation to warmer (subtropical) environments that was to be carried out at the Univ. of California was only about to begin (1926) and 'Lassen', the first cultivar truly adapted to southern coastal California, was not to be released until 1945 (H.E. Thomas and E.V. Goldsmith, 1945).

While California yields per unit area were the highest in the nation prior to World War II, they were only $\approx 1$ to $2 \mathrm{t}$ higher than those of the highest-yielding other states, a relatively insignificant difference (Tables 1 and 2).

California strawberry production was effectively terminated for the duration of World War II, starting in 1942, and was not resumed until the return of the Japanese-descended farmers after the war ended. PostWorld War II yields in California more than tripled prewar yields, and commercial strawberry production has been dominated by $\mathrm{Cal}-$ ifornia ever since (Tables 3 and 4). Excluding California, average yields over all other states did not increase during 1949-54 (Table 3). The principal reason for the large increase in postwar yield was the development and re-

Received for publication 18 Sept. 1989. The cost of publishing this paper was defrayed in part by the payment of page charges. Under postal regulations, this paper therefore must be hereby marked advertisement solely to indicate this fact. lease of the Univ. of California strawberry cultivars.

The Univ. of California Strawberry Breeding Program was started in 1924-26 by A.G. Plakidas, a U.C. Berkeley pathologist, and continued by W.T. Home in a successful effort to identify virus-tolerant material that might be useful in breeding (Wilhelm and Sagen, 1974).

H.E. Thomas and E.V. Goldsmith, also of the Dept. of Plant Pathology, Berkeley,

Table 1. Production, hectarage, and yield of the 20 leading strawberry-producing states in 1919 (from Hedrick, 1926, D. 369).

\begin{tabular}{|c|c|c|c|c|c|c|}
\hline \multirow[b]{3}{*}{ State } & \multicolumn{6}{|c|}{ U.S. strawberry production } \\
\hline & \multicolumn{2}{|c|}{ Crop } & \multicolumn{2}{|c|}{ Area } & \multicolumn{2}{|c|}{ Yield } \\
\hline & $\%$ & Rank & $\%$ & Rank & $t \cdot h a^{-1}$ & Rank \\
\hline Tennessee & 7.4 & 1 & 9.1 & 1 & 2.0 & 19 \\
\hline Missouri & 7.3 & 2 & 7.2 & 2 & 2.5 & 8 \\
\hline Michigan & 7.1 & 3 & 6.7 & 4 & 2.6 & 7 \\
\hline Arkansas & 6.5 & 4 & 7.0 & 3 & 2.3 & 15 \\
\hline California & 6.1 & 5 & 4.2 & 8 & 3.6 & 1 \\
\hline Maryland & 5.1 & 6 & 5.9 & 5 & 2.1 & 17 \\
\hline New York & 4.8 & 7 & 4.1 & 9 & 3.0 & 4 \\
\hline New Jersey & 4.2 & 8 & 4.7 & 6 & 2.9 & 6 \\
\hline Pennsylvania & 4.1 & 9 & 3.4 & 12 & 3.0 & 3 \\
\hline Ohio & 4.0 & 10 & 3.5 & 11 & 2.9 & 5 \\
\hline Illinois & 3.9 & 11 & 4.2 & 7 & 2.3 & 14 \\
\hline Iowa & 3.7 & 12 & 3.7 & 10 & 2.5 & 10 \\
\hline Washington & 3.6 & 13 & 2.6 & 17 & 3.5 & 2 \\
\hline Louisiana & 3.0 & 14 & 3.4 & 13 & 2.2 & 16 \\
\hline Wisconsin & 2.9 & 15 & 3.1 & 14 & 2.4 & 13 \\
\hline Indiana & 2.4 & 16 & 2.8 & 16 & 2.1 & 18 \\
\hline Oregon & 2.3 & 17 & 2.3 & 18 & 2.5 & 11 \\
\hline Minnesota & 2.3 & 18 & 2.3 & 19 & 2.5 & 9 \\
\hline Delaware & 2.3 & 19 & 2.9 & 15 & 1.9 & 20 \\
\hline North Carolina & 2.1 & 20 & 1.8 & 20 & 2.5 & 12 \\
\hline Total & 85.6 & & 84.4 & & Mean 2.6 & \\
\hline
\end{tabular}

Table 2. Production, hectarage, and yield of the 20 leading strawberry-producing states in 1941 (Federal-State Market News Service, 1955).

\begin{tabular}{|c|c|c|c|c|c|c|}
\hline \multirow[b]{3}{*}{ State } & \multicolumn{6}{|c|}{ U.S. strawberry production } \\
\hline & \multicolumn{2}{|c|}{ Crop } & \multicolumn{2}{|c|}{ Area } & \multicolumn{2}{|c|}{ Yield } \\
\hline & $\%$ & Rank & $\%$ & Rank & $\mathrm{t} \cdot \mathrm{ha} \mathrm{a}^{-1}$ & Rank \\
\hline Arkansas & 12.4 & 1 & 11.4 & 2 & 3.2 & 6 \\
\hline Louisiana & 10.8 & 2 & 13.2 & 1 & 2.4 & 14 \\
\hline Oregon & 10.8 & 3 & 7.9 & 3 & 4.0 & 3 \\
\hline Michigan & 6.6 & 4 & 6.0 & 5 & 3.3 & 7 \\
\hline Washington & 6.5 & 5 & 4.2 & 7 & 4.6 & 2 \\
\hline Tennessee & 6.5 & 6 & 6.3 & 4 & 3.0 & 10 \\
\hline California & 6.1 & 7 & 3.5 & 10 & 5.0 & 1 \\
\hline North Carolina & 5.1 & 8 & 3.9 & 8 & 3.8 & 4 \\
\hline Wisconsin & 3.4 & 9 & 3.1 & 13 & 3.2 & 8 \\
\hline New York & 3.3 & 10 & 3.0 & 14 & 3.2 & 9 \\
\hline Ohio & 3.2 & 11 & 2.6 & 16 & 3.6 & 5 \\
\hline Florida & 3.1 & 12 & 3.2 & 11 & 2.8 & 11 \\
\hline Kentucky & 2.6 & 13 & 3.9 & 9 & 2.0 & 17 \\
\hline Virginia & 2.3 & 14 & 4.2 & 6 & 1.6 & 20 \\
\hline Alabama & 2.2 & 15 & 2.3 & 17 & 2.8 & 12 \\
\hline Maryland & 2.2 & 16 & 2.9 & 15 & 2.2 & 16 \\
\hline Missouri & 1.9 & 17 & 3.2 & 12 & 1.8 & 19 \\
\hline Pennsylvania & 1.9 & 18 & 1.9 & 20 & 2.8 & 13 \\
\hline New Jersey & 1.7 & 19 & 2.1 & 19 & 2.4 & 15 \\
\hline Indiana & 1.5 & 20 & 2.2 & 18 & 2.0 & 18 \\
\hline Total & 94.1 & & 91.0 & & Mean 2.9 & \\
\hline
\end{tabular}


(continued from inside front cover)

years (Table 6). Of the others, 'Dormer' became an important cultivar in Japan, but was never used elsewhere.

A. Etter (1887-1950), a private breeder from Ettersburg, Calif., must be credited with developing important breeding stock that led, in part, to the development of the UC cultivars; in particular, to virus resistance and adaptation to relatively warm southern coastal conditions, via 'Lassen'. In retrospect, Etter's most important contribution was the breeding of derivatives from California $\mathrm{Fra}$ garia chiloensis, perhaps the most important of which was a hybrid between an F. chiloensis plant that he collected from Cape Mendocino (not far from Ettersburg) and an unknown cultivated octoploid $(2 \mathrm{n}=56)$ that he, by mistake, assumed to be $F$. vesca (diploid 'Alpine', $2 \mathrm{n}=14$ ). This important hybrid was 'Ettersburg 121'.

In commenting about the great vigor of 'Ettersburg 121', Etter (1919) said,

"In general, it would seem to favor poor land to do its best. I have seen 121's growing on land too poor to grow wild grass and weeds, and producing bountiful yields while in the same climate and locality where they were on rich land they simply indulged in riotous living and did nothing worthwhile."

We note that great or even excessive vigor is typical of California $F$. chiloensis cultivar hybrids. 'Ettersburg 121' is the hybrid that was the direct ancestor of 'Lassen', released by Thomas and Goldsmith in 1945. 'Lassen' was characterized by superior adaptation and was the only cultivar of the original five that was derived directly from California $F$. chiloensis.

According to Thomas and Goldsmith (1945), the double-cropping trait was derived for the most part from the 'Nich Ohmer' parentage of the original five cultivars. In this regard, it is worth noting that, of the five originals, only 'Dormer' failed to have the double-cropping trait and that it has the lowest percentage of 'Nich Ohmer' ancestry (Table 5).

'Lassen', the best-adapted of the original five, has the broadest ancestral base (Table 5 ) and tolerates extreme inbreeding (successive selfing) the best of the five. In contrast, 'Shasta', the other originally successful cultivar of the five, had a relatively narrow ancestral base and tolerates extreme inbreeding the least successfully of all. In fact, it is difficult to impossible to maintain self-pollinated lines of 'Shasta'. They lack vigor to the point that they tend to die in the second generation.

Bringhurst and Voth bred the successful cultivars that have subsequently replaced 'Lassen' and 'Shasta' in California, starting with 'Fresno' and 'Tioga' and continuing successively through 'Douglas', 'Pajaro', 'Chandler', and 'Selva' (Table 6).

'Lassen' has been the most important ancestral cultivar in the development of these California-bred cultivars, apparently stabilizing at $\approx 20 \%$ to $25 \%$ of the ancestry (Table 7). 'Shasta' has been a relatively poor ancestor and the only reason it appears in the
Table 3. Production, hectarage, and yield of the 20 leading strawberry-producing states in 1949-1954 (Federal-State Market News Service, 1956).

\begin{tabular}{|c|c|c|c|c|c|c|}
\hline \multirow[b]{3}{*}{ State } & \multicolumn{6}{|c|}{ U.S. strawberry production } \\
\hline & \multicolumn{2}{|c|}{ Crop } & \multicolumn{2}{|c|}{ Area } & \multicolumn{2}{|c|}{ Yield } \\
\hline & $\%$ & Rank & $\%$ & Rank & $\mathrm{t} \cdot \mathrm{ha}$ & Rank \\
\hline California & 27.4 & 1 & 6.5 & 7 & 15.5 & 1 \\
\hline Oregon & 12.3 & 2 & 12.6 & 1 & 3.7 & 5 \\
\hline Washington & 8.1 & 3 & 6.9 & 6 & 4.4 & 2 \\
\hline Michigan & 7.8 & 4 & 7.6 & 5 & 3.8 & 4 \\
\hline Louisiana & 5.8 & 5 & 9.0 & 3 & 2.6 & 14 \\
\hline Arkansas & 5.5 & 6 & 11.0 & 2 & 1.8 & 20 \\
\hline Tennessee & 5.0 & 7 & 7.8 & 4 & 2.3 & 16 \\
\hline New York & 3.5 & 8 & 3.3 & 12 & 4.0 & 3 \\
\hline Florida & 2.5 & 9 & 3.7 & 8 & 2.5 & 15 \\
\hline Virginia & 2.2 & 10 & 3.5 & 10 & 2.6 & 13 \\
\hline New Jersey & 2.2 & 11 & 2.4 & 13 & 3.5 & 6 \\
\hline Missouri & 2.0 & 12 & 3.6 & 9 & 2.1 & 19 \\
\hline Kentucky & 2.0 & 13 & 3.5 & 11 & 2.1 & 18 \\
\hline North Carolina & 1.4 & 14 & 1.8 & 15 & 2.8 & 11 \\
\hline Ohio & 1.3 & 15 & 1.7 & 16 & 2.9 & 9 \\
\hline Maryland & 1.2 & 16 & 1.4 & 19 & 3.3 & 8 \\
\hline Wisconsin & 1.2 & 17 & 1.4 & 20 & 3.3 & 7 \\
\hline Oklahoma & 1.1 & 18 & 2.0 & 14 & 2.2 & 17 \\
\hline Indiana & 1.1 & 19 & 1.4 & 18 & 2.9 & 10 \\
\hline Pennsylvania & 1.0 & 20 & 1.5 & 17 & 2.7 & 12 \\
\hline Total & 94.6 & & 92.6 & & Mean $2.9^{2}$ & \\
\hline
\end{tabular}

${ }^{2}$ Does not include California.

Table 4. Production, hectarage, and yield for the commercial U.S. strawberry-producing states in 1987 (Federal-State Market News Service, 1987).

\begin{tabular}{|c|c|c|c|c|c|c|}
\hline \multirow[b]{3}{*}{ State } & \multicolumn{6}{|c|}{ U.S. strawberry production } \\
\hline & \multicolumn{2}{|c|}{ Crop } & \multicolumn{2}{|c|}{ Area } & \multicolumn{2}{|c|}{ Yield } \\
\hline & $\%$ & Rank & $\%$ & Rank & $\mathrm{t} \cdot \mathrm{ha}{ }^{-1}$ & Rank \\
\hline California & 74.0 & 1 & 37.7 & 1 & 54.9 & 1 \\
\hline Florida & 9.9 & 2 & 11.0 & 3 & 25.1 & 2 \\
\hline Oregon & 8.4 & 3 & 17.5 & 2 & 13.4 & 3 \\
\hline Washington & 2.2 & 4 & 5.6 & 5 & 10.7 & 4 \\
\hline New York & 1.4 & 5 & 6.3 & 4 & 6.3 & 7 \\
\hline Michigan & 1.2 & 6 & 4.9 & 6 & 6.7 & 6 \\
\hline Ohio & 0.7 & 7 & 3.1 & 8 & 5.8 & 9 \\
\hline Pennsylvania & 0.5 & 8 & 2.9 & 9 & 4.7 & 11 \\
\hline North Carolina & 0.4 & 9 & 4.7 & 7 & 2.5 & 13 \\
\hline Wisconsin & 0.4 & 10 & 2.6 & 10 & 4.0 & 12 \\
\hline Louisiana & 0.4 & 11 & 1.3 & 12 & 8.1 & 5 \\
\hline New Jersey & 0.4 & 12 & 1.8 & 11 & 5.8 & 8 \\
\hline Arkansas & $>0.1$ & 13 & 0.4 & 13 & 5.6 & 10 \\
\hline Mean & & & & & $6.6^{2}$ & \\
\hline
\end{tabular}

${ }^{2}$ Does not include California and Florida.

Table 5. Ancestry of the original Univ. of California cultivars, given in percentages.

\begin{tabular}{lccccc}
\hline \hline & \multicolumn{5}{c}{ Cultivar } \\
\cline { 2 - 6 } Ancestor & Lassen & Shasta & Donner & Sierra & Tahoe \\
\hline Nich Ohmer & & & Percent & & \\
Howard 17 & 25.0 & 25.0 & 12.5 & 50.0 & 25.0 \\
Marshall & 18.7 & 37.5 & 12.5 & 25.0 & -- \\
Missionary & 18.7 & 6.2 & 25.0 & 6.3 & 12.5 \\
Fendall & 12.5 & $\cdots$ & 6.2 & -- & $\cdots$ \\
Royal Sovereign & 9.4 & $\cdots$ & $\cdots$ & $\cdots$ & $\cdots$ \\
$F$. chiloensis & 6.3 & 31.3 & 6.2 & 18.7 & $\cdots$ \\
Redheart & 4.7 & $\cdots$ & $\ldots$ & $\cdots$ & $\cdots$ \\
Narcissa & --- & $\cdots$ & 25.0 & $\cdots$ & 50.0 \\
Unknown & $\cdots$ & $\cdots$ & $\cdots$ & $\cdots$ & 12.5 \\
\hline
\end{tabular}

'Includes 'Banner' as 'Marshall'. 
Table 6. Important or potentially important Univ. of California strawberry cultivars, type-day-neutral (D-N) or short-day (S-D) and period of use.

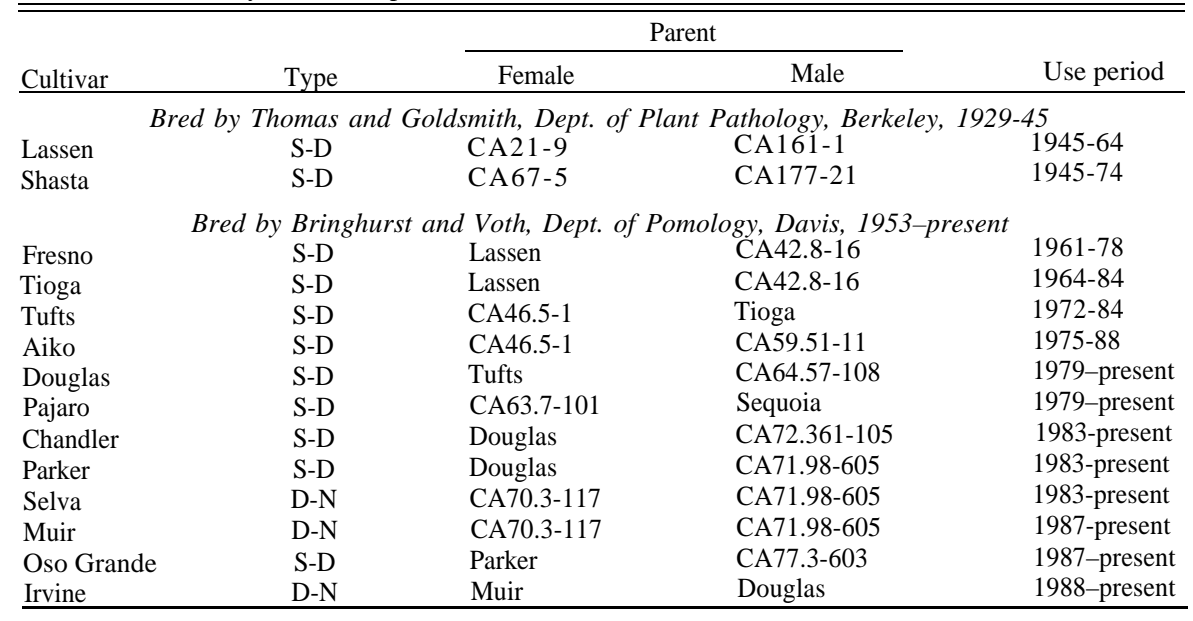

Table 7. 'Lassen', 'Shasta', and F. virginiana glauca ancestry of second group of important Univ. of California short-day-type cultivars and first group of day-neutrals.

\begin{tabular}{|c|c|c|c|c|c|}
\hline \multirow[b]{2}{*}{ Cultivar } & \multirow{2}{*}{$\begin{array}{c}\text { Seed } \\
\text { (year) }\end{array}$} & \multirow{2}{*}{$\begin{array}{c}\text { Release } \\
\text { (year) }\end{array}$} & \multicolumn{3}{|c|}{ Ancestry (\%) } \\
\hline & & & Lassen & Shasta & F. virginia glauca \\
\hline \multicolumn{6}{|l|}{ Short-day } \\
\hline Tioga & 1953 & 1964 & 50.0 & 0 & 0 \\
\hline Tufts & 1963 & 1972 & 25.0 & 0 & 0 \\
\hline Aiko & 1963 & 1975 & 31.2 & 0 & 0 \\
\hline Pajro & 1971 & 1979 & 12.2 & 0 & 0 \\
\hline Douglas & 1972 & 1979 & 31.2 & 0 & 0 \\
\hline Chandler & 1977 & 1983 & 25.0 & 0 & 0 \\
\hline Parker & 1977 & 1983 & 21.9 & 0 & 0 \\
\hline Oso Grande & 1981 & 1987 & 26.6 & 0 & 0 \\
\hline \multicolumn{6}{|l|}{ Day-neutral } \\
\hline Fern & 1972 & 1983 & 15.6 & 3.1 & 3.1 \\
\hline Selva & 1975 & 1983 & 14.1 & 3.1 & 3.1 \\
\hline Muir & 1975 & 1987 & 14.1 & 3.1 & 3.1 \\
\hline Mrak & 1975 & 1987 & 17.2 & 3.1 & 3.1 \\
\hline Yolo & 1975 & 1987 & 7.8 & 3.1 & 3.1 \\
\hline Irvine & 1982 & 1988 & 22.7 & 1.6 & 1.6 \\
\hline Seascape & 1983 & 1989 & 22.7 & 1.6 & 1.6 \\
\hline Capitola & 1983 & 1989 & 23.8 & 1.6 & 1.6 \\
\hline
\end{tabular}

pedigrees at all is because it was used in the original hybridization with $F$. virginiana glauca that gave rise to the California dayneutral cultivars presently in use or under test, principally 'Selva'. It is unlikely that further infusions of 'Shasta'-derived genes will occur. They are systematically being eliminated at the same rate as those from $F$. virginiana glauca.

Much of the statement cited above (Hedrick, 1925) is now obsolete because of the success of the Univ. of California Strawberry Breeding Program. The effect of this program has been felt world-wide, because the California cultivars now dominate production in subtropical and even tropical areas wherever strawberries are grown. Furthermore, it is likely that progress in breeding will continue in the Univ. of California program. Gains in morphological and physiological traits, including yield, fruit quality, and disease and pest resistance, are anticipated (Bringhurst and Voth, 1989).

\section{Literature Cited}

Bringhurst, R. S.. and V. Voth. 1989. California strawberry cultivars. Fruit Var. J. 43(1): 12-19.

Etter, A.E. 1919. Making a canning strawberry. Pacific Rural Press. p. 2.

Federal-State Market News. 1941. Marketing California strawberries. Fed.-State Market News, San Francisco.

Federal-State Market News. 1956. Marketing California strawberries. Fed.-State Market News, San Francisco.

Federal-State Market News. 1987. Marketing California strawberries. Fed.-State Market News, San Francisco.

Hedrick, V.P. 1925. The small fruits of New York. J.B. Lyons, Albany, N.Y.

Thomas, H.E. and E.V. Goldsmith. 1945. The Shasta, Sierra, Lassen, Tahoe and Dormer strawberries. Univ. Calif. Coll. Agr. Bul. 690 Wilhelm, S. and J.E. Sager. A history of the strawberry. Univ. of Calif. Div. Agr. Sci.

Royce S. Bringhurst, Victor Voth AND DOUglas ShaW Univ. of California Davis, CA 95616 